\title{
PENGARUH PERILAKU KONSUMEN DAN LABEL HALAL PRODUK MAKANAN RUMAH TANGGA TERHADAP KEPUTUSAN KONSUMSI DI PALANGKA RAYA (Keluarga Mahasiswa Ekonomi Syariah IAIN Palangka Raya)
}

\author{
Yeni Herliani, Rahmaniar, dan Fuad Muhajirn Farid \\ IAIN Palangka Raya
}

\begin{abstract}
Every individual has different manners for making choices, including choosing a need and desire. In the modern world of today has come a wide selection of products both local and international standards one of which is a food product. Namely food production in the country for food products imported from abroad, as well as processed food products such as cottage industries. Existing halal label on food products would have been very impact and influence for consumers, particularly Muslim consumers are encouraged to consume Thayyib food and halal. For this study will focus on the effect of consumer behavior and halal label food products by household to consumption decisions in Palangka Raya (Student Association of Islamic Economics at IAIN Palangka Raya) to determine the effect of consumer behavior and halal label food products by households to consumption decision analysis techniques Correlation Product Moment using SPSS 18.0.

This research is quantitative descriptive research type ex post facto, and perform data analysis with multiple regression test. Data collection methods the authors used observations and questionnaires. From the test result perfomed on the instrument 20 respondents to the uestion number 40 items declared valid and can be used to collect the data in the study sample. The population in this study were all students of Islamic Economics at IAIN Palangka Raya in force from 2012 to 2015. While the study sample were 75 respondents students of Faculty of Islamic Economics and Business, Departement of Islamic Economics at IAIN Palangka Raya, and from the number of respondents were given a qquestionnaire to be answered. Data analysis technique used is Multiple Regression.

The result of this study indicate that obtained from the F test (simultaneous) amounted tp 7.132 , then in accordance with the F test criteria then Ho is rejected. This means that there are significant effect between consumer behavior and halal label together or simultaneously on consumption decisions, the results obtained from the value of $\mathrm{R}$ Square of 0.165 which means that the consumer behavior variables (X1) and label halal food products household (X2) 16,5\% have influence on consumer decision variable (Y). while the remaining $83,5 \%$ is influenced by other factors.
\end{abstract}

Keywords: halal label, consumer behavior, consumption decision

\section{PENDAHULUAN}

Persepsi setiap individu berbeda-beda, dalam memilih, mengatur dan menafsirkan suatu pilihan produk atau barang yang akan dikonsumsinya. Tentulah bagi seorang muslim yang beriman sangat memperhatikan kejelasan atau label dari produk yang ia konsumsi. Label halal sangatlah berpengaruh dan penting. Dengan adanya akal kita dapat membedakan perkara antara yang hak dan yang bathil, yang baik dan buruk. Hendaknya produk yang kita konsumsi telah menjalani proses pemeriksaan kehalalan dan dinyatakan halal (telah memiliki sertifikat 
halal). Produk yang belum mendapat sertifikat halal atau berlabel halal tidak berarti dinyatakan haram, tapi dinyatakan tidak terjamin kehalalannya atau masih diragukan.

Banyak beredar berbagai macam bahan atau produk makanan yang masih belum ada keterangan halal atau label halal dan diragukan kejelasan proses pembuatan juga bahannya. Seperti disekitar tempat tinggal kita banyak berbagai pilihan makanan olahan kemasan yang membuat pembeli dapat memilih makanan yang diinginkan, khususnya makanan yang banyak dijual disekitar tempat perkuliahan mahasiswa ekonomi syariah. Banyak mahasiswa yang berbeda pendapat mengenai pilihan produk makanan yang ingin di konsumsi, mulai dari mempertimbangkan keinginan kebutuhan maupun melihat kemasan label produk. Setiap konsumen muslim akan memperhatikan produk makanan yang ia beli, dan dari setiap perilaku individu muslim khususnya mahasiswa mahasiswi Ekonomi Syariah IAIN Palangka Raya pasti berbeda-beda. Masih ada saja orang-orang yang menghiraukan tentang halalnya produk bahan makanan yang dibeli. Oleh karena itu dengan adanya latar belakang ini saya tertarik meneliti tentang "Pengaruh Perilaku Konsumen dan Label Halal Produk Makanan Rumah Tangga Terhadap Keputusan Konsumsi di Palangka Raya (Mahasiswa Ekonomi Syariah IAIN Palangka Raya)".

\section{Landasan Teori}

Perilaku konsumen adalah proses dan aktivitas ketika seseorang berhubungandengan pencarian, pemilihan, penggunaan, pembelian, serta pengevaluasian produk dan jasa demi memenuhi kebutuhan dan keinginan. Perilaku konsumen adalah hal yang mendasari konsumen untuk membuat keputusan pembelian. Teori perilaku konsumen (consumer behavior) mempelajari bagaimana manusia memilih diantara berbagai pilihan yang dihadapinya dengan memanfaatkan sumberdaya (resources) yang dimilikinya. ${ }^{1}$

Menurut James F Engel, Roger D Blackwell, Paul W Miniart dalam saladinterdapat tiga faktor yang mempengaruhi perilaku konsumen yaitu: 1) Pengaruh lingkungan, terdiri dari budaya, kelas sosial, keluarga dan situasi. 2) perbedaan dan pengaruh individu, terdiri dari motivasi, pengetahuan, sikap, kepribadian, gaya hidup, dan demografi. 3) proses psikologis terdiri dari pengolahan informasi, pembelajaran, perubahan sikap, dan perilaku².

Label merupakan keterangan yang melengkapi suatu kemasan barang yang berisi tentang bahan-bahan yang digunakan untuk membuat suatu barang tersebut. Labeling berkaitan erat dengan pemasaran. Label merupakan bagian dari suatu produk yang menyampaikan informasi mengenai produk dan penjual. Sebuah label bisa merupakan bagian dari kemasan, atau bisa pula merupakan etiket (tanda pengenal) yang menempel atau melekat pada produk. Label produk (product label) adalah bagian dari pengemasan sebuah produk yang mengandung informasi mengenai produk atau penjualan produk. Secara garis besar terdapat tiga macam label yaitu:

1) Brand Label, yaitu nama merek yang diberikan pada produk atau dicantumkan pada kemasan.

2) Descriptive Label, yaitu label yang memberikan informasi obyektif mengenai penggunaan, konstruksi atau pembuatan, perawatan atau perhatian dan kinerja produk, serta karakteristik-karakteristik lainnya yang berhubungan dengan produk.

3) Grade Label, label yang mengidentifikasi penilaian kualitas produk dengan suatu huruf, angka, atau kata ${ }^{3}$.

\footnotetext{
1Mustafa Edwin Nasution, dkk, Pengenalan Eksklusif Islam, Jakarta: Kencana, 2007, hal. 56.

2Ratni, Http:/ / ratni_itp.staff.ipb.ac.id, diakses pada tanggal 20 April 2016.

3Wahyu Budi Utami,http:/ / digilib.uinsuka.ac.id/ 8244/ 1/ BAB\%20I,\%20IV,\%20DAFTAR\%20PUSTAKA.pdf., diakses pada tanggal 18 maret 2016.
} 
Terdapat beberapa faktor internal yang relevan terhadap proses pengambilan keputusan konsumen:

1) Motivasi (motivation) merupakan suatu dorongan yang ada dalam diri manusia untuk mencapai tujuan tertentu.

2) Persepsi (perception) merupakan hasil pemaknaan seseorang terhadap stimulus atau kejadian yang diterimanya berdasarkan informasi dan pengalamannya terhadap rangsangan tersebut.

3) Pembentukan sikap (attitude formation) merupakan penilaian yang ada dalam diri seseorang yang mencerminkan sikap suka/ tidak suka seseorang akan suatu hal.

4) Integritas (integration) merupakan kesatuan antara sikap dan tindakan. Integrasi merupakan respon atas sikap yang diambil. Perasaan suka akan mendorong seseorang untuk membeli dan perasaan tidak suka akan membulatkan tekad seseorang untuk tidak membeli produk tersebut.

\section{HASIL DAN PEMBAHASAN}

Dalam proses pengambilan keputusan setiap orang berbeda beda, ada yang sederhana dan kompleks. Tergantung pemikiran dan kebiasaan setiap individu. Proses pengambilan keputusan membeli sebelum membeli suatu produk atau jasa, umumnya konsumen melakukan evaluasi untuk melakukan pemilihan produk atau jasa.

Sedangkan untuk menentukan signifikan dari sebuah hipotesis yang telah dirumuskan maka diperlukan kaidah keputusan yang akan dijadikan pedoman yaitu sebagai berikut.

1) Jika nilai reabilitas (taraf signifikan) 0,05 lebih kecil atau sama dengan nilai Sig atau $(0,05<$ Sig), maka Ho diterima dan Ha ditolak artinya tidak signifikan.

2) Jika nilai probabilitas 0,05 lebih besar atau sama dengan nilai Sig $(0,05>$ Sig), maka Ho ditolak dan Ha diterima artinya signifikan.4

Hipotesis:

$$
\begin{aligned}
& \text { Ho = tidak ada hubungan } \\
& \text { Ha = Ada hubungan } \\
& \text { Jika Sig. }<0,05 \text {, maka tolak Ho } \\
& \text { Jika Sig. }>0,05 \text { maka terima Ho }
\end{aligned}
$$

Menurut teori Engel (2006), dinyatakan bahwa pengambilan keputusan konsumen dipengaruhi oleh budaya, kelas sosial, pengaruh pribadi, keluarga dan situasi. Keputusan pembelian konsumen dipengaruhi faktor internal atau faktor pribadi (persepsi, keluarga, pengetahuan, sikap, usia, gaya hidup) kerap memainkan peran penting dalam pengambilan keputusan konsumen ${ }^{5}$. Menurut Engel, Blakckwell \& miniard faktor yang mempengaruhi perilaku konsumen untuk melakukan keputusan pembelian adalah salah satunya pengaruh lingkungan dan pengaruh individual. menurut Engel (2006) faktor internal (pribadi) keputusan pembelian konsumen juga dipengaruhi oleh pengetahuan produk. Engel juga menjelaskan bahwa pengetahuan produk meliputi: kesadaran akan kategori dan merek produk di dalam kategori produk, terminology produk, atribut dan ciri produk, dan kepercayaan tentang kategori produk secara umum mengenai merek yang spesifik ${ }^{6}$. Berdasarkan teori tersebut dapat disimpulkan perilaku konsumen

\footnotetext{
${ }_{4}$ Ridwan \& Sunarto, Pengantar Statistik untuk Penelitian: Pendidikan, Sosial, Komunikasi, Ekonomi, dan Bisnis, Bandung: Alfabeta, 2007, hal.278.

5 Etta Mamang Sangadji dan Sopiah, Perilaku Konsumen: Pendekatan Praktis, Yogyakarta: Andi Offset, 2013, hal.40.

6 Etta Mamang Sangadji dan Sopiah, Perilaku Konsumen: PendekatanPraktis, ...hal. 44.
} 
dan juga atribut merek produk memiliki pengaruh terhadap keputusan pembelian atau keputusan konsumsi.

Diketahui F hitung sebesar 7,132. Apabila menggunakan F tabel sebesar 2,732 maka dengan membandingkan antara F hitung dan F tabel diperoleh 7,132 >2,732. Berdasarkan kriteria uji F :

Ho diterima bila $F$ hitung $<$ F tabel

Ho ditolak bila $F$ hitung $>\mathrm{F}$ tabel

Berdasarkan kriteria uji F tersebut, maka Ho ditolak. Artinya ada pengaruh secara signifikan antara perilaku konsumen dan label halal secara bersama-sama atau serentak terhadap keputusan konsumsi. Dan dapat disimpulkan bahwa perilaku konsumen dan label halal berpengaruh terhadap keputusan konsumsi di Palangka Raya (Keluarga mahasiswa ekonomi syariah IAIN Palangka Raya).

Berdasarkan hasil analisis statistik uji t pada (tabel 4.12) didapatkan model dari keputusan konsumsi yang dipengaruhi oleh variabel perilaku konsumen dan label halal produk makanan rumah tangga, sesuai model umum sebagai berikut: keputusan konsumsi $(\mathrm{Y})=34,344+$ 0,524* perilaku konsumen $(\mathrm{X} 1)+0,415 *$ Label halal produk makanan rumah tangga $(\mathrm{X} 2)$. Dimana kedua variabel tersebut yaitu perilaku konsumen dan label halal produk makanan rumah tangga berpengaruh signifikan terhadap keputusan konsumsi. Dapat dilihat dari nilai t yang sesuai dengan hipotesisnya jika nilai t hitung $>$ dari $\mathrm{t}$ tabel atau $\mathrm{Sig}<0,05$, maka $\mathrm{H}_{0}$ ditolak yang artinya variabel-variabel tersebut berpengaruh signifikan terhadap variabel respon atau keputusan konsumsi.

Selanjutnya akan dilihat apakah model tersebut sesuai dengan kriteria Goodness of fit (kebaikan model) dapat dilihat dari tabel Anova (tabel 4.13) didapatkan nilai f sebesar 7,132, maka sesuai dengan hipotesis bahwa f hitung lebih besar dari $f$ tabel atau nilai Sig. $<0,05$ maka $\mathrm{H}_{0}$ ditolak yang artinya model tersebut dengan variabel-variabel bebas $(\mathrm{X})$ berpengaruh terhadap variabel terikat (Y) Signifikan, sehingga model tersebut sudah sesuai dengan kriteria Goodness of fit (kebaikan model). Artinya, ada pengaruh secara signifikan antara perilaku konsumen dan label halal secara bersama-sama atau serentak terhadap keputusan konsumsi. Dan dapat disimpulkan bahwa perilaku konsumen dan label halal berpengaruh terhadap keputusan konsumsi di Palangka Raya (Keluarga mahasiswa ekonomi syariah IAIN Palangka Raya). Hasil penelitian juga menunjukkan bahwa nilai R Square sesuai dengan (tabel 4.14) sebesar 0,165 yang dapat diartikan bahwa variabel perilaku konsumen dan label halal produk makanan rumah tangga mempunyai pengaruh sebesar 16,5\% terhadap variabel keputusan konsumsi, sedangkan 83,5\% sisanya variabel keputusan konsumsi dipengaruhi oleh faktor-faktor lain di luar dari variabel perilaku konsumen dan label halal.

Variabel perilaku konsumen dan label halal produk makanan rumah tangga memiliki pengaruh yang signifikan terhadap hubungan antara keputusan konsumsi, maka hipotesis kedua yang menyatakan bahwa perilaku konsumen dan label halal berpengaruh terhadap keputusan konsumsi dapat dibuktikan kebenarannya.

Bedasarkan data yang telah diuraikan pada bab-bab sebelumnya dengan menggunakan analisis regresi linear ganda, maka dapat disimpulkan sebagai berikut:

Hasil yang didapatkan dari uji $\mathrm{F}$ (serentak) sebesar 7,132, maka sesuai dengan tersebut maka Ho ditolak. Artinya, ada pengaruh secara signifikan antara perilaku konsumen dan label halal secara bersama-sama atau serentak terhadap keputusan konsumsi. Dan dapat disimpulkan bahwa perilaku konsumen dan label halal berpengaruh terhadap keputusan konsumsi di Palangka Raya (Keluarga mahasiswa ekonomi syariah IAIN Palangka Raya).

Berdasarkan kaidah keputusan dari hipotesis, nilai probabilitas 0,05 lebih besar atau sama dengan nilai probabilitas Sig. Atau $(0,000<0,05)$, maka Ho ditolak dan Ha diterima, artinya 
signifikan.Hasil penelitian juga menunjukkan bahwa nilai R Square sebesar sebesar 0,165 yang dapat diartikan bahwa variabel perilaku konsumen dan label halal produk makanan rumah tangga mempunyai pengaruh sebesar 16,5\% terhadap variabel keputusan konsumsi, sedangkan 83,5\% lainnya dipengaruhi oleh faktor-faktor di luar dari variabel perilaku konsumen dan label halal.

\section{PENUTUP}

Hasil penelitian ini menunjukkan bahwa diperoleh dari uji F (serentak) sebesar 7,132, maka sesuai dengan kriteria uji $\mathrm{F}$ tersebut maka Ho ditolak. Artinya, ada pengaruh secara signifikan antara perilaku konsumen dan label halal secara bersama-sama atau serentak terhadap keputusan konsumsi. Dan dapat disimpulkan bahwa perilaku konsumen dan label halal berpengaruh terhadap keputusan konsumsi di Palangka Raya (Keluarga Mahasiswa Ekonomi Syariah IAIN Palangka Raya).

Berdasarkan kaidah keputusan dari hipotesis, nilai probabilitas 0,05 lebih besar atau sama dengan nilai probabilitas Sig. Atau $(0,000<0,05)$, maka Ho ditolak dan Ha diterima, artinya signifikan.Hasil penelitian juga menunjukkan bahwa nilai R Square sebesar sebesar 0,165 yang dapat diartikan bahwa variabel perilaku konsumen dan label halal produk makanan rumah tangga mempunyai pengaruh sebesar 16,5\% terhadap variabel keputusan konsumsi, sedangkan 83,5\% lainnya dipengaruhi oleh faktor-faktor di luar dari variabel perilaku konsumen dan label halal. Hal ini dapat menjelaskan bahwa pengaruh perilaku konsumen dan label halal produk makanan rumah tangga terhadap keputusan konsumsi di Palangka Raya berpengaruh.

\section{DAFTAR PUSTAKA}

Ahsin, W Alhafidz. 2010. Fikih Kesehatan. Jakarta: Amzah.

Al Arif, M Nur Rianto. 2010. Teori Mikro Ekonomi. Jakarta: Kencana.

Arikunto, Suharsimi. 1998. Penelitian Suatu Pendekatan Praktek. Jakarta: Rineka Cipta

Bakri, Asafri Jaya. 1996. Konsep Maashid Syari’ah. Jakarta: PT Raja Grafindo Persada.

Bungin, Burhan.2006. Metodologi Penelitian Kuantitatif: Komunikasi, Ekonomi, dan Kebijakan Publik Serta Ilmu-ilmu Lainnya. Jakarta: Kencana.

Consuelo G. Sevilla, dkk. 2006. Pengantar Metode Penelitian. Jakarta: UI-Press.

Darmawan, Deni. 2013. Metode Penelitian Kuantitatif. Bandung: PT Remaja Rosdakarya.

Fauzia, Ika Yunia, dan Abdul Kadir Riyadi. 2014. Prinsip Ekonomi Islam (Perspektif Maqashid alSyari'ah) Jakarta: Kencana.

Husein Umar. 2011. Metode Penelitian Untuk Skripsi dan Tesis Bisnis. Jakarta: Rajawali Pers.

Indrawan WS. 2013. Kamus Lengkap Bahasa Indonesia.Jombang: Lintas Media Jombang.

Jusmaliani. 2008. Bisnis Berbasis Syariah. Jakarta: Bumi Aksara.

Karim, Adiwarman A. 2007. Ekonomi Mikro Islam. Jakarta: PT Raja Grafindo Persada. 
Mardalis. 2004. Metode Penelitian Suatu Pendekatan Proposal, Jakarta: Bumi Aksara.

Muflih, Muhammad. 2006. Perilaku Konsumen Dalam Perspektif Ilmu Ekonomi Islam. Jakarta: PT Raja Grafindo. 2006.

Mustafa Edwin Nasution, dkk. 2007. Pengenalan Eksklusif Islam. Jakarta: Kencana.

Philip Kotler, Kevin Lane Keller. 2008. Manajemen Pemasaran. Indonesia: Macanan Jaya Cemerlang.

Pusat Pengkajian dan Pengembangan Ekonomi Islam (P3EI) Universitas Islam Indonesia Yogyakarta. 2008. Ekonomi Islam. Jakarta: PT Raja Grafindo Persada.

Qardhawi, Yusuf. 2005. Halal dan Haram Dalam Islam. Rembang: Karya Utama Surabaya.

Riduwan. 2010. Metode dan Teknik Menyusun Tesis. Bandung: Alfabeta.

Shaleh, Abdul Rahman, dan Muhbib Abdul Wahab. 2004. Psikologi dalam Suatu Pengantar Perspektif Islam. Jakarta: Kencana.

Sudjino, Anas. 2010. Pengantar Statistis Pendidikan. Jakarta: Rajawali Press.

Sugiyono. 2009. Metode Penelitian Bisnis Pendekatan Kuantitatif , Kualitatif, dan R\&D. Bandung: Alfabeta.

Syekh Muhammad Yusuf Qardhawi. 2003. Halal dan Haram dalam Islam. Surabaya: PT Bina Ilmu Offset.

Tim Penulis. 2003. Buku Pedoman Strategi Kampanye Sosial Produk Halal.Jakarta: Depag RI.

Tim penulis. 2013. Pedoman Verifikasi Produk Halal. Jakarta: Proyek Pembinaan Pangan Halal.

Wahbah Az-Zuhaili. 2011. Fiqih Islam Wa Adillatuhu. Jakarta: Darul Fikr.

Youdsa Amirman. 1993. Penelitian dan Statistik Pendekatan. Jakarta: Bumi Aksara. 